\title{
Estimating Economic Burden and Factors Perceived to Be Associated With Lumpy Skin Disease in Cattle in Namisindwa District, Eastern Uganda
}

Isaac Ongom ( $\sim$ ongomisaacwarren@gmail.com )

Makerere University https://orcid.org/0000-0001-9627-656X

Steven Odongo

Makerere University

Aggrey Siya

Stellenbosch University

Francis Ejobi

Makerere University

Research article

Keywords: Notifiable disease, Transboundary Animal disease, Epidemiology, Animal Health Economics, Cattle, Uganda

Posted Date: December 4th, 2020

DOl: https://doi.org/10.21203/rs.3.rs-30528/v1

License: (9) This work is licensed under a Creative Commons Attribution 4.0 International License. Read Full License 


\section{Abstract}

\section{Background}

Globally, livestock contributes about $40 \%$ of agricultural output sustaining livelihoods and food security of almost a billion people. In Uganda, livestock contributes $5.2 \%$ and $12.7 \%$ to the total national GDP and agricultural GDP, respectively. In districts like Namisindwa, diseases like Lumpy Skin Disease (LSD) affect the sector undermining its trade and production. Studies on the economic impact and risk factors have not been undertaken in such areas. This study thus sought to unravel information regarding economic impact and perceived risk factors associated with LSD in Namisindwa district. A cross sectional study involving quantitative approaches was employed in this study. Dependent variables were period prevalence and associated economic losses due effect of LSD on cattle herds while independent variable were potential factors influencing spread of the disease among cattle herds. The financial impact assessment was based on the farmers' calendar year.

\section{Results}

The total economic losses incurred by farmers in Namisindwa district in a single outbreak of LSD was estimated at UGX 574,999,741 (USD 155,405). The most prominent economic loss due to LSD was attributed to low milk yield in lactating cattle as well as poor draught power performance. Other major contributions to economic losses due to LSD after the aforementioned two factors were cost of veterinary services and mortalities of cattle. Economic losses associated with loss of calves, and skin losses were perceived to be the lowest. Introduction of new animals, communal grazing and access to veterinary services were significantly associated with outbreaks of Lumpy Skin Disease. Specifically, farmers with access to veterinary services were less likely to be affected with the rampant spread of the LSD in their cattle, $O R=.03361$ and $P$-value $<.05$.

\section{Conclusion}

There is need for Ministry of Agriculture, Animal Industry and Fisheries in Uganda to advance interventions for prevention and control of LSD in the district. Larger scale and rigorous studies ought to be undertaken also to understand the risk factors and economic impact of LSD outbreaks.

\section{Background}

Globally, livestock contributes about $40 \%$ of agricultural output sustaining livelihoods and food security of almost a billion people in the world[1]. In Sub-Saharan Africa, the livestock sector accounts for about $30 \%$ of the agricultural GDP and almost $60 \%$ of the value of edible livestock product is generated by cattle[2]. Livestock provide a safety net to resource poor farmers and traders along the value chain throughout the developing world[3]. In Uganda, livestock production is one of the major economic activities which contribute $5.2 \%$ and $12.7 \%$ to the total national GDP and agricultural GDP, respectively [4]. Furthermore, livestock provide a potential pathway out of poverty for rural producers and other actors 
along the marketing chain where market access exists, constitute a means of investment and perform important networking functions[5]. Namisindwa district among other districts in Uganda, livestock sector accounts for a significant contribution to the districts' revenue, income to the poorest households and a major source of fertilizer in coffee-banana plantations[6]. Despite the huge economic importance of livestock to households and to nations[7], the sector is faced with numerous challenges including diseases [8]. One such disease is LSD with one of its endemic hotspots being eastern Uganda [9].

LSD is viral disease of cattle caused by a virus of the family Poxviridae, also known as Neethling virus[10]. It is characterized by fever, enlarged lymph nodes, firm and circumscribed nodules in the skin, and ulcerative lesions particularly of the mucous membrane of the mouth[11]. It is anotifiable disease in Uganda[12].

LSD is one of the epizootic diseases of cattle associated with mortality and morbidity thus economic losses to livestock farmers[13][14]. Many studieshave recognized LSD one of the major Trans-boundary Animal Diseases (TADs) limiting livestock production in a wide range of agro-climatic zones[15][16][17].

Also, LSD disrupts livestock trade and related products locally and internationally[18]. For instance, in Turkey where about $\$ 241.903 .500$ US dollars was lost during a two year outbreak of LSD[19]. It is a growing and serious problem in developing countries like Uganda, where capacity to cope with the cost and logistics of controlling the disease is quite limited[20]. The disease is spread widely in all regions in Uganda[9].Namisindwa district located in Eastern Uganda (considered as a hotspot of the disease) is no exception. The District Veterinary Officer, surveillance reports of 2017 reveal Lumpy Skin Disease as one of the diseases affecting livestock production in the district. However, information on the impacts and risk factors associated with LSD outbreaks are not well documented. This study therefore sought to document the economic impacts of lumpy skin disease and perceived associated risk factors for the occurrence of the disease.

LSD threatens household nutrition and incomes due to its morbidity, mortality and has significant socioeconomic impact nationally[21].The apparent morbidity and mortality rates of LSD were approximated at $9.11 \%$ and $0.51 \%$, respectively in Iraq[16]. It's occurrence in livestock industry results into milk yield loss, infertility, skin and hide loss, abortion and death[18]. Decrease in animal body weight due to LSD can be up to $80 \%$ [11]. In Uganda, the disease has severely affected livestock sector in many districts including Namisindwa[9].Despite its devastating effects, less has been done to address the effects associated with LSD inNamisindwa.Namisindwa district has high human population explosion[22], dynamiceconomic activities[23] and climate[24]. This is partly because less is known about the risk factors associated with Lumpy Skin Disease occurrence and its impact on farmers' income and livelihood in the district. This study therefore sought to unravel information regarding perceived factors associated with occurrence of LSD and the economic impact of the disease in Namisindwa district.

\section{Methods}




\section{Description of the study area}

The study was conducted in Namisindwa district, Bugisu region, eastern Uganda [25]. Namisindwa District is bordered by Bududa District to the North, Kenya to the East and South, Tororo District to the South-west, and Manafwa District to the West[26]. The district headquarters at Namisindwa are located at Bupoto approximately 40 kilometers $(25 \mathrm{mi})$, by road, South-east of Mbale. Namisindwa district GPS coordinates are $00^{\circ} 49^{\prime} \mathrm{N} 34^{\circ} 23^{\prime} \mathrm{E}$, having a population of people approximately $178,746[26]$. Generally, 97 percent of the human population live in rural areas while only about 3 percent in are urban dwellers within the district [26]. The districts experience bimodal type of rainfall with the highest in the first season of March to June and second season which is normally light in August to November[27]. A short dry spell is between June to July while December to March spell is longer[27]. In general, there are no extreme temperature ranges; this condition is attributed to close proximity to Mt. Elgon NationalForest park [24]. Agriculture is the major economic activity in the district as majority of farmers are small holders who grow both perennial (e.g. coffee among others), annual crops (e.g. bananas, onions, maize, Irish, etc.) and rear livestock (e.g. cattle, goats, sheep, poultry,pigsetc.). Livestock production systems are both extensive and semi intensive and most breeds kept are cross breeds[28].

\section{Study population}

The study population included cattle farming households and their respective cattle herds. A household was a group of people living together and cattle herd is a group of cattle of the same farm owned by the household(s).

\section{Study design}

A cross sectional design involving quantitative approaches was employed in this study. Dependent variables were period prevalence and associated economic losses due effect of LSD on cattle herds while independent variable were potential factors influencing spread of the disease among cattle herds. The financial impact assessment was based on the farmers' calendar year which involve four seasons: beginning of dry season, (November and December),end of dry season,(January and February), beginning of rainy season, (March, AprilandMay), end of rainy season,(July, August, September, and October). This was from December 2017 to December 2018.

\section{Sample size determination}

The sample size was estimated using Cochran formal [29] for sample size determination as shown below;

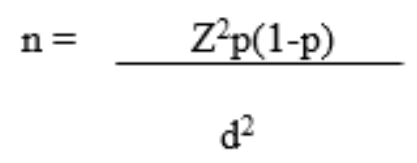


Where: $n$, was required sample size; $Z$ was the critical Z-score at $95 \%$ confidence level; $p$ was the expected prevalence of LSD in Namisindwa; $d$ was desired absolute precision. Assuming $32 \%$ of cattle herds $(p=0.32)$ in Namisindwa district suffered LSD in the last one year[9], at $95 \%$ level of confidence $(Z=1.96)$ and $5 \%$ level of precision $(d=0.05)$, the sample size $(n)$ was;

$$
\mathrm{n}=\frac{1.96^{2} \times 0.32 \times(1-0.32)}{0.05^{2}}
$$

$n=334.4 \approx 336$

\section{Sampling strategy}

A multistage sampling was carried out at Sub County and Parish levels. Nine (9) Sub counties were selected randomly from the 18 sub counties in the district these include: Namabya, Bubutu, Bukhabusi, Mukoto, Bukiabi, Lwakhakha, Bumbo, Namboko and Bukhaweka. Three parishes were selected from each sub county randomly. At parish level, participating households were selected by systematic random sampling from list of households having cattle herds generated with the help of sub county veterinary extension worker.

\section{Data collection}

A semi-structured questionnaire was developed (Additional file 1), pre-tested and administered to respondents (selected household heads). It captured data mainly on location, household size, education, religion, knowledge of LSD, cattle farming systems, herd size and structure, draught power, whether herd suffered from LSD in 2017/2018, number of cows that aborted due to LSD, number of cattle that died from LSD, average milk produced by cows, price of milk, price of cattle, vaccination against LSD, cost of treatment or vaccination in controlling LSD.

\section{Economic impact of lumpy skin disease}

This was done by quantifying the secondary variables and fitting them in a relevant model.

Economic loss $=$ cost of mortality of infected cattle + cost of morbidity + cost of veterinary intervention.

\section{Where;}

\section{1) Mortality}

- Mortality of cattle occur due to starvation and dehydration as a result of painful swellings in the oropharynx, intestines and secondary bacterial infection,

\section{2) Morbidity}


- Permanent damage to skin due to nodular inflammatory swellings that become necrotic and sloughs off leaving raw painful wound.

- Loss of drought power due to general body weakness and lesions in that restricts movement

- Loss of beef result from emaciation/cachexia/wasting occur due to interference in feeding

- Loss of milk production also results from anorexia

- Abortions occur due to fever and intrauterine infection

- Painful lesions on sheath of bulls and debility in females interferes with reproduction

\section{3) Cost of veterinary intervention}

- In control of LSD through treatment of infected animals and vaccination with vaccine to minimize impact

\section{Perceived risk factors associate with lumpy skin disease}

The perceived risk factors were identified through assessment of the relationship (multivariate logistic regression) between the disease status of the herds and household and herd level characteristics. Inferences were based on odds ratio, chi-square and p-value.

\section{Data management and analysis}

\section{Economic impact of lumpy skin disease}

Data from household survey questionnaires was coded, cleaned and entered into Microsoft Excel spread sheet 2010. This data was imported to STATA software (version 13) [30] for analysis. Chi-square test was used to compute the probability value(p-value) and significance differences[31].

Economic impacts resulting from lumpy skin disease occurrence in the study area was determined through financial costs and losses in Uganda Shillings and US dollar. This was calculated based on livestock respondents' perceptions. A model that was used in this study was adopted from[18] and [32] to estimate costs of lumpy skin disease in form of morbidity (milk, abortions, draught power and hide), mortality and control expenditures. The mathematical model considered direct costs associated with lumpy skin disease only.

$T L=A+B+C:$

Where

$\mathrm{TL}=$ Total loss associated with the disease.

$A=$ Loss associated with mortality, and $B=$ Losses associated with morbidity, $C=$ Costs of veterinary intervention. 


\section{Estimation of Mortality (A)}

- Mortality of cattle occur due to starvation and dehydration as a result of painful swellings (in the oropharynx and intestines), and secondary bacterial infection.

- Economic value of cattle that die of LSD during the period of outbreak can be computed from the formula:

Cost of mortality of infected cattle (Value of cattle that die)

$=($ Population at risk $\mathrm{X}$ Mortality risk $) \mathrm{X}$ average price of cattle

Where Population at risk $=$ number of cattle in the whole district (affected district)

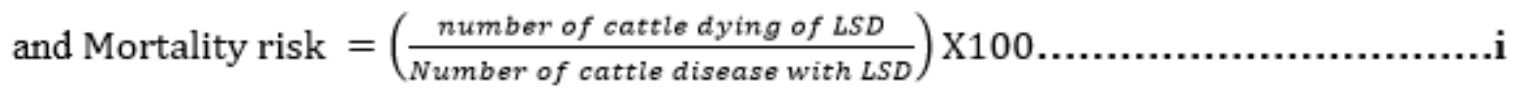

\section{Estimation of morbidity}

(i) Skin losses due to LSD

\section{Loss of skin= Number of infected cattle that did not die $X$ Average price of} skin.

\section{(ii) Milk losses due to LSD}

Milk loss due to abortion= Volume of milk lost due to abortion $\mathrm{X}$ price of milk.

Where,

Volume of milk lost due to abortion= number of cows that aborted $X$ Duration of milking $X$ daily milk yield.

Where,

Number of cows that aborted $=$ Number of infected cows $X$ Abortion risk

Where,

Number of infected cows $=$ Number of infected cattle $X$ average proportion cows in herds

Value of milk lost among non-aborted infected cows due to LSD =volume of milk lost among non-aborted infected cows $X$ average price of milk.

Where, 
Volume of milk lost among non-aborted infected cows = number of infected cows that did not abort $X$ Daily milk yield $X$ Percentage reduction in milk yield due to $L S D$.

Where,

Number of infected cows that did not abort $=$ Number of infected cows $X$ (1-abortion risk)

Therefore,

Total value of milk lost due to LSD in the cattle population = Value of milk lost due to abortion +Value of milk lost among non-aborted infected cows due to LSD.

\section{(iii) Cost of veterinary intervention}

Value of treatment of infected cattle $=$ Number of cattle infected $X$ treatment cost per cattle..

Vaccination

Value of vaccination of cattle in the district $=$ Population of cattle at risk of LSD in the district X unit cost of vaccination. (iv)

\section{(iv)Draught power losses}

Draft losses $=$ total number of affected cattle $X$ proportion of oxen in the herd $X$ Unit cost of ploughing an acre of land $X$ proportion of days spent without ploughing.

\section{Perceived risk factors associated with Lumpy Skin Disease}

Data from household survey questionnaires was coded and entered into spread sheet using Microsoft Excel spread sheet 2010. This data was imported to STATA software (version 13) [30] for analysis.

\section{Results}

\section{Socio-demographic characteristics of respondents}

The sampled households were inhabitants of nine sub counties in Namisindwa district (Table 1). Majority of the respondents were male $80.7 \%(n=271)$, while the rest were female. Going by religion, Catholics had the biggest proportion 38.4\% ( $n=129)$; followed by Anglicans at 35.1\% ( $n=118)$; Muslims at $15.8 \%$ $(n=53)$ and least were Seventh Day Adventists (Table 1). Considering education level, respondents had attained mainly primary education $47.0 \%(n=158)$ while a few of them had attained tertiary level education $8.7 \%(n=29)$ (Table 1$)$.The major sources of income of the respondents were mixed farming $27.4 \%(n=92)$ involving livestock and crop production. 
In terms of sex of the animals, male cattle were at more risk compared to their female counterparts (Table .2). Similarly, cross bred cattle and cattle at old age were more at risk compared to their respective counter parts. In terms of morbidity, the groups that were affected most were females (70.3\%), old (41\%) and cross bred (42.0\%) cattle.

The following computations were made based on data obtained from primary sources

1. Average price of hide UGX $15,455.357$

2. Average price of a newly born calf UGX $192,514.9$

3. Number of aborted calves were23

4. Number of aborted cows were 23

5. Average quantity of milk yield per cow 5.5 Liters

6. Average price per litre of milk was UGX 1019.4

7. Number of lactating infected cows were 76

8. Average cost of treatment of LSD infected cattle UGX 110,979.3

9. Average cost of vaccination UGX 2000

10. Number of infected oxen's 52

11. Average days spent without ploughing 26

12. Unit cost of ploughing an acre UGX $119,861.7$

\section{Economic impact of Lumpy Skin Disease in Namisindwa district}

The total economic losses incurred by farmers in a single outbreak of LSD are estimated at UGX $574,999,741$ approximating to USD 155,406 in only investigated sub counties of Namisindwa district. The most prominent economic loss due to LSD is attributed to low milk yield in lactating cattle as well as poor drought power performance. Next major contributions to economic losses due to LSD after the aforementioned two factors are cost of veterinary services and mortalities of cattle. Economic losses associated with loss of calves, and skin losses were perceived to be the lowest (Figure 2).

\section{Economic loss due to mortality of cattle as a result of LSD}

Economic loss due to mortality of cattle as a result of LSD

$=$ Number of cattle infected with LSD X Mortality risk X Average price of cattle

Where Mortality risk (\%) $=[($ Number of cattle dying of LSD $) /($ Number of LSD infected cattle) $] \times 100$ 
Where, number of cattle dying of LSD $=39$, number of cattle diseased with LSD $=199$

Therefore, from equation (II) Mortality risk $(\%)=(39 / 199) * 100=20 \%$

From equation (I), economic loss due to mortality of cattle as a result of LSD $=199 \mathbf{X} 0.2 \mathbf{X} 1$, $290,386.90$ UGX

Economic loss due to mortality of cattle as a result of LSD $=$ UGX $51,357,398.62$

\subsubsection{Economic losses due to morbidity}

Economic loss due to morbidity $=($ value of skin lost due to LSD+ value of calves lost due to abortion + value of milk lost due to LSD).

- Value of skin lost due to LSD = Number of infected cattle that did not die $X$ average price of skin (III)

Where, Number of infected cattle that did not die $=$ total number of infected cattle $(n=199)$ minus total number of infected which died $(n=39)=(199-39=160$; and average price of skin $=$ UGX. $15,455.357$

Therefore, from equation (III), Value of skin lost due to LSD $=160 \times 15,455.357$

Value of skin loss $=$ UGX 2,472,857.143

- Value of calves lost due to abortion= number of calves lost due to abortion caused by LSD X Price of a calf

Where, number of calves lost due to abortion caused by LSD $=23$ and price of a calf at birth was

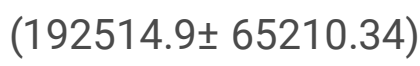

Therefore, value of calves lost due to abortion $=23 \times 192,514.9$

Since an animal produces at an average of once in a year,

Value of calves lost in abortion due to LSD $=$ UGX4, 427,842.7

\section{- Value of milk lost due to LSD in lactating cattle}

$=$ Value of milk lost due to abortion+ Value of milk lost among non-aborted infected cows due to LSD Where, value of milk lost due to abortion = Number of animals that aborted $\mathrm{X}$ average quantities of milk produced per cow $\mathrm{X}$ price of each liter of milk.

Where, number of animals that aborted $=23$, average quantities of milk produced per cow $=5.5 \pm 3.1$ liters and price of each liter of milk = UGX1019.4 \pm 124.6 
Therefore, value of milk lost due to abortion = 23 X 5.5 X $1019.4=$ UGX 128,954.1/= per day

Value of milk lost among non-aborted infected cows due to $L S D=$ number of lactating infected cows $X$ average quantities of milk produced per cow $\mathrm{X}$ average price of each liter of

milk

Where, number of lactating infected cows $=76$, average quantities of milk produced per cow per day= $5.5 \pm 3.1$ liters, average price of each liter of milk $=$ UGX1019.4 \pm 124.6

Therefore, Value of milk lost among non-aborted infected cows due to LSD=76 X 5.5 X 1019.4

$=U G X 426,109.2$ per day

Therefore, from equations (IV) and (V), total value of milk lost due to LSD in lactating cattle $=$ $128,954.1+426,109.2$

$=$ UGX 555, 063.3 per day

Therefore, on average 210 days of lactating, total value of losses associated with milk lost due to LSD = $555,063.3 * 210$

$=$ UGX $116,563,293$ per lactating period

- Cost of veterinary intervention

Cost of veterinary intervention $=$ cost of treatment of infected cattle+cost of vaccination of cattle

Where, cost of treatment= Number of cattle infected $X$ Average treatment cost per cattle...

Number of cattle infected $=190$, average treatment cost per cattle= UGX $110979.3 \pm 124227.8$

Cost of treatment $=190 \times 110979.3=$ UGX 21,086,067

- Cost of vaccination of cattle against LSD

= Population of cattle at risk of LSD X Unit cost of vaccination

Where, population of cattle at risk of LSD in the district in the year $2017=25,000$ and Unit cost of vaccination $=$ UGX 2,000

Cost of vaccination of cattle against $L S D=25,000 \times 2000$

$=$ UGX 50,000,000

Therefore, total cost of veterinary intervention $=21,086,067+50,000,000$

Page $11 / 26$ 
$=$ UGX 71, 086,067 annually

(IV) Draught power

$=$ Total number of affected oxen X Average number of days spent without ploughing X Unit cost of ploughing an acre in a planting season

Where, total number of affected oxen $=52$, Average number of days spent without ploughing $=26.4 \pm 17.1$ and Unit cost of ploughing an acre in a planting season = UGX 119,861.7 \pm 207400.2

Therefore, total value lost to draught power $=52 \times 26.4 \times 119,861.7$

$=U G X 164,546,141.8$ per planting season

In a year, there are two seasons, therefore, annual costs due to draught power losses $=164,546,141.8 X$ 2

$=$ UGX 329,092,283.5

NOTE:

1. Off take rate of beef was not considered in this study because farmers would not recall or estimate exact beef loss during the time of the outbreak.

2. Reproductive rate was difficult to determine because it has long term morbidity and farmers cull animals that recover to guard against reoccurrence and transmission of the disease.

3. Indirect losses or costs such as restricted trade and cattle movement was not considered in this study

\section{Risk factors contributing to the occurrence and transmission of Lumpy Skin DiseaseinNamisindwa district}

Households that frequently introduced new cattle in their herd[Odd ratio (3.9)]were 3time more likely to have cases of LSD in their farms than those that maintainedold herd, cattle from households that share common grazing places (e.g. play grounds, water points, and market grounds) [Odd ratio (OR) 10] were 10 times more likely to contract LSD than those in households practicing zero grazing system. Farmers with access to veterinary services were less likely to have cases of the LSD in their farms [Odd ratio (OR) $0.3]$ than those that never accessed veterinary services or do self-medication. Cattle on farms that never controlled ectoparasites were at a high risk of contracting Lumpy Skin Disease [Odd ratio (OR) 20.0] 20 times than those on farms that practiced control of ectoparasites through routine application of Acaricide on their cattle. 
Regarding months when LSD outbreaks are common, respondents noted the months of July, August and September to be associated with peak periods of LSD (Figure 3).

\section{Discussion}

Firstly, this study reports economic losses associated with mortality and morbidity of cattle due to LSD, and secondly the risk factors associated with LSD .Other authors previously noted that morbidity due to LSD leads to low carcass weight[33], increases treatment costs [34], and decreases quality of animal products such as milk, skin and beef[14]. More so affected oxen has reduced draught power which affects productivity at household level [34]. Based on computation of data obtained from farmers in this study, it was estimated that a single outbreak of Lumpy Skin Disease in Namisindwa amounts to USD $155,405.335$. The reported economic loss was found to originate from mortality of adult cattle and abortions, loss of milk production in sick and aborted animals, cost of veterinary services, poor performance of traction oxen, and low quality of hides from the affected cattle. Besides, administration of antibiotics treatment in lactating animals results into drug residues in milk making it unfit for human consumption [35].Importantly, indirect losses from restriction of cattle movements and trade also contribute to the economic losses; however, this was not estimated due to the limited scope of the study and inadequacy of data on revenue collected within the study area. Investigation of these indirect losses required data from cattle traders and commercial officer.

Investigation of potential risk factors influencing the occurrence and transmission of LSD was conducted. Factors analyzed were cattle breed, control of ectoparasites, grazing system, and regular introduction of new animals into the herd. With respect to cattle breed it was found that exotic breeds were more likely to be suffering from the disease than the indigenous breeds. Higher prevalence of LSD could be explained by low resistance of the exotic cattle breed to an endemic infection. It was also found that lack of ectoparasites control, communal grazing, and introduction of new animals were significant factors associated with LSD outbreaks. The role of ectoparasites in the transmission of LSD is well known; therefore, it was not surprising that farms that were not controlling ectoparasites like ticks and biting flies, registered high rates of infections compared those farms which practiced ectoparasites control.

Communal grazing was listed to contribute to LSD outbreaks in other studies in Ethiopia[36]. During communal grazing direct such as through grooming and mating; and indirect contacts such as contact with saliva of infected on pasture and biting flies would aid transmission of Lumpy Skin Disease between infected and 'clean' herds. Additional to that farmer's in Namisindwapractices bulls fights as a creational activity and show of pride of owning the biggest and furious bull which gather many sub counties both within and out the district which increases the risk of LSD spread compared to those who purely do dairy farming

Furthermore, farms that regularly introduce new cattle were more likely to have LSD Introduction of new animals into a herd without following proper quarantine procedure is one of the means by which diseases 
are transmitted between farms.

It is likely that cattle that were sold originated from infected herd and the owners of such farms usually tend to sell off their animals before they go down with the disease thereby transmitting the disease to 'clean' farms. This is common among illegal traders who cross the borders between Kenya and Uganda. This result thus provides an avenue for design of epidemiological interventions to address LSD. Animal trading has been shown in some studies to contribute to spread and transmission of LSD similarly to the results in this current study[14][37]. Respondents pointed to introduction of new animals from cattle market as one of the factors contributing to LSD transmission to cattle originally on the farm.

Ectoparasites mentioned by respondents to contribute to LSD in this study relates with the epidemiology of LSD [16]. This indicates the knowledge among communities regarding LSD thus can inform design of control interventions.

\section{Conclusions}

- The economic losses associated with LSDsingleoutbreak in the investigated sub counties were due to mortality and morbidity amounting toUGX574,999,741 (USD 155,406) in Namisindwa district.

- Besides, information on the risk factors for the occurrence and transmission of Lumpy Skin Disease were gathered from farmers and indicates that introduction of new cattle, communal grazing and ectoparasites were the major drivers of LSD spread and transmission in the district.

- MAAIF and Namisindwa District Local Government should take interest and implement effective containment of the disease using available means.

- To guarantee the success and sustainability of the control program, constant involvement and participation of the affected community should be greatly encouraged.

- A country wide study directed at establishing total economic loses, the national incidence, geographical and spatiotemporal distribution of LSD should be conducted.

- Indigenous knowledge and methods of LSD control should be obtained from farmers in the disease endemic area, scrutinized and integrated into the national control program of the LSD.

\section{Abbreviations}




\begin{tabular}{|ll|}
\hline LSD & Lumpy Skin Disease \\
\hline UGX & Uganda Shillings \\
\hline USD & United States Dollar \\
\hline OR & Odds Ratio \\
\hline GDP & Growth Domestic Product \\
\hline TADs & Trans-boundary Animal Diseases \\
\hline UBOS & Uganda Bureau of Statistics \\
\hline MAAIF & Ministry of Agriculture, Animal Industry and Fisheries \\
\hline
\end{tabular}

\section{Declarations}

\section{Ethical approval and consent to participate}

Approval for this study was obtained from Namisindwa District Local Government (Number: CRNAMD 2010/13). Written and informed consent was obtained from the interviewed cattle owners and extension service providers to participate in the study.

\section{Consent for Publication}

Written and informed consent was obtained from Namisindwa District Local Government, cattle owners and extension service providers about publication of the findings from this study.

\section{Availability of data and material}

Data is available upon request

\section{Competing interests}

We declare no competing interests in this study.

\section{Funding}

This study was privately funded by the corresponding author.

\section{Authors' contributions}




\section{Author Contribution}

IO Designed the study, mobilized funds for the study and produced the first draft of the manuscript

SO Supervised the study and assisted in writing the manuscript

AS Assisted in data analysis and reviewing the manuscript

FE Supervised the study and assisted in writing the manuscript

All authors read and approved the manuscript

\section{Acknowledgements}

We acknowledge support from Makerere University College of Veterinary Medicine for assisting in approval process of the study. We also thank the leadership and community members of Namisindwa District for the support during data collection.

\section{Environmental Considerations}

All equipments, tools and materials used during the study period was disposed in accordance with the recommendations of the National Environment Management Authority.

\section{Limitation to the study}

The following were the imitations that hindered the study process;

1. Language barrier

2. Collection of reliable data

3. Limited resources

4. Demand for money by the respondents.

\section{Mitigation measures}

The above limitations were solved by;

1. Hiring of a native to interpret for me within the district

2. Explaining the importance of the study to the people and its benefit to the animal population

3. Outsourcing and lobbying for help from the District and other interested persons in the study

4. Explaining the importance of the study to the area leaders; carry along a consent letter from the district to accept me carry out a student study.

\section{Gender Consideration}

The study was undertaken while recognizing gender norms within the target population. 


\section{References}

1. McLeod A. World Livestock 2011 - Livestock in food security. 2011.

2. Thornton PK. Livestock production: recent trends, future prospects. Philos Trans R Soc Lond B Biol Sci. 2010;365:2853-67.

3. Herrero M, Thornton PK, Gerber P, Reid RS. Livestock, livelihoods and the environment: understanding the trade-offs. Current Opinion in Environmental Sustainability. 2009;1:111-20.

4. Uganda Bureau of Statistics. Uganda Census of Agriculture 2008/2009. 2010.

5. Tarawali S, Herrero M, Descheemaeker K, Grings E, Blümmel M. Pathways for sustainable development of mixed crop livestock systems: Taking a livestock and pro-poor approach. Livest Sci. 2011.

6. Nalubwama SM, Mugisha A, Vaarst M. Organic livestock production in Uganda: Potentials, challenges and prospects. Tropical Animal Health and Production. 2011.

7. Swanepoel F, Stroebel a., Moyo S. The role of livestock in developong communities: Enhancing multifunctionality. 2008.

8. Benson T, Mugarura S. Livestock development planning in Uganda: Identification of areas of opportunity and challenge. Land use policy. 2013;35:131-9.

9. Ochwo S, VanderWaal K, Munsey A, Ndekezi C, Mwebe R, Okurut ARA, et al. Spatial and temporal distribution of lumpy skin disease outbreaks in Uganda (2002-2016). BMC Vet Res. 2018.

10. Al-Salihi K. A. Lumpy Skin disease: Review of literature. Mirror Res Vet Sci Anim. 2014.

11. Abutarbush SM, Ababneh MM, Al Zoubi IG, Al Sheyab OM, Al Zoubi MG, Alekish MO, et al. Lumpy Skin Disease in Jordan: Disease Emergence, Clinical Signs, Complications and Preliminaryassociated Economic Losses. Transbound Emerg Dis. 2015.

12. Kitching RP. Vaccines for lumpy skin disease, sheep pox and goat pox. Vaccines for OIE list A and emerging animal diseases, 16-18 September, 2002. 2003.

13. Abdulqa HY, Rahman HS, Dyary HO, Othman HH. Lumpy Skin Disease. Reprod Immunol Open Access. 2016.

14. Abera Z, Degefu H, Gari G, Ayana Z. Review on Epidemiology and Economic Importance of Lumpy Skin Disease. Int J Basic Appl Virol. 2015.

15. Beard PM. Lumpy skin disease: A direct threat to Europe. Veterinary Record. 2016.

16. Al-Salihi KA, Hassan IQ. Lumpy Skin Disease in Iraq: Study of the Disease Emergence. Transbound Emerg Dis. 2015.

17. Mercier A, Arsevska E, Bournez L, Bronner A, Calavas D, Cauchard J, et al. Spread rate of lumpy skin disease in the Balkans, 2015-2016. Transbound Emerg Dis. 2018.

18. Hailu B. Economic Importance and Control Techniques of Lumpy Skin Diseases. Anim Vet Sci. 2015.

19. Ince ÖB, Çakir S, Dereli MA. Risk analysis of lumpy skin disease in Turkey. Indian J Anim Res. 2016. 
20. Ayudhya SNN, Assavacheep P, Thanawongnuwech R. Transboundary and Emerging Diseases. One World - One Heal Threat Emerg Swine Dis An Asian Perspect. 2012.

21. Molla W, de Jong MCM, Gari G, Frankena K. Economic impact of lumpy skin disease and cost effectiveness of vaccination for the control of outbreaks in Ethiopia. Prev Vet Med. 2017.

22. Uganda Bureau of Statistics. National Population and Housing Census 2014 - Main Report. Uganda Bureau of Statistics. 2016.

23. Uganda Bureau of Statistics (UBOS). Uganda National Household Survey 2012/2013. 2014.

24. Jiang B, Bamutaze Y, Pilesjö P. Climate change and land degradation in Africa: A case study in the Mount Elgon region, Uganda. Geo-Spatial Inf Sci. 2014;17:39-53.

25. UBOS. The republic of uganda. Summ Rep Uganda Census Agriclture 2008/2009. 2010.

26. UBOS. National Population and housing Census. Uganda Bur Stat. 2014;:73 pp.

27. Mubangizi N, Kyazze FB, Mukwaya PI. Smallholder farmers' perception and adaptation to rainfall variability in Mt. Elgon resion, Eastern Uganda. Int J Agric Ext. 2017.

28. Mumba M, Kutegeka S, Nakangu B, Munang R, Sebukeera C. Ecosystem-based adaptation (EbA) of African mountain ecosystems: Experiences from mount elgon, Uganda. In: Climate Change Adaptation Strategies - An Upstream-downstream Perspective. 2016.

29. Donner A. Sample size requirements for stratified cluster randomization designs. Stat Med. 1992.

30. StataCorp. Stata Statistical software. 2013.

31. Greenland S, Senn SJ, Rothman KJ, Carlin JB, Poole C, Goodman SN, et al. Statistical tests, P values, confidence intervals, and power: a guide to misinterpretations. Eur J Epidemiol. 2016.

32. Rushton J, Lyons N. Economic impact of Bluetongue: a review of the effects on production. Vet Ital. 2015.

33. Tuppurainen ESM, Babiuk S, Klement E. Lumpy Skin Disease. 2018.

34. Gari G, Bonnet P, Roger F, Waret-Szkuta A. Epidemiological aspects and financial impact of lumpy skin disease in Ethiopia. Prev Vet Med. 2011.

35. Bilandžić N, Kolanović BS, Varenina I, Scortichini G, Annunziata L, Brstilo M, et al. Veterinary drug residues determination in raw milk in Croatia. Food Control. 2011.

36. Gari G, Waret-Szkuta A, Grosbois V, Jacquiet P, Roger F. Risk factors associated with observed clinical lumpy skin disease in Ethiopia. Epidemiol Infect. 2010.

37. Molla W, Frankena K, Gari G, Kidane M, Shegu D, de Jong MCM. Seroprevalence and risk factors of lumpy skin disease in Ethiopia. Prev Vet Med. 2018.

\section{Tables}

Table 1: Socio-economic characteristics of the respondents 


\begin{tabular}{|c|c|c|}
\hline Socio-demographic characteristics $(n=336)$ & Freq. & Percent \\
\hline \multicolumn{3}{|l|}{ SubCounty } \\
\hline Bubutu & 44 & 13.1 \\
\hline Bukhabusi & 38 & 11.3 \\
\hline Bukhaweka & 35 & 10.4 \\
\hline Bukiabi & 39 & 11.6 \\
\hline Bumbo & 39 & 11.6 \\
\hline Lwakhakha & 33 & 9.8 \\
\hline Mukoto & 38 & 11.3 \\
\hline Namabya & 30 & 8.9 \\
\hline Namboko & 40 & 11.9 \\
\hline \multicolumn{3}{|l|}{ Gender } \\
\hline Male & 271 & 80.7 \\
\hline Female & 65 & 19.4 \\
\hline \multicolumn{3}{|l|}{ Religion } \\
\hline Anglican & 118 & 35.1 \\
\hline Catholic & 129 & 38.3 \\
\hline Muslim & 53 & 15.4 \\
\hline SDA & 30 & 8.9 \\
\hline Others & 6 & 1.8 \\
\hline \multicolumn{3}{|l|}{ Education level } \\
\hline None & 69 & 20.5 \\
\hline Primary & 158 & 47.0 \\
\hline Secondary & 80 & 23.8 \\
\hline Tertiary & 29 & 8.7 \\
\hline
\end{tabular}




\begin{tabular}{|lll|}
\hline Major source of income & & \\
\hline Crop farming & 50 & 14.8 \\
\hline Mixed farming & 158 & 47.02 \\
\hline Livestock farming & 92 & 27.3 \\
\hline Business person & 21 & 6.2 \\
\hline Formal job & 15 & 4.5 \\
\hline
\end{tabular}

Table 2: Mortality and case fatality rates according to age, sex and breed of cattle

\begin{tabular}{|lllllll|}
\hline & $\begin{array}{l}\text { Number } \\
\text { at risk }\end{array}$ & $\begin{array}{l}\text { Number } \\
\text { affected }\end{array}$ & $\begin{array}{l}\text { Number of } \\
\text { death }\end{array}$ & $\begin{array}{l}\text { Morbidity } \\
\text { rate (\%) }\end{array}$ & $\begin{array}{l}\text { Mortality } \\
\text { rate (\%) }\end{array}$ & $\begin{array}{l}\text { Case } \\
\text { fatality (\%) }\end{array}$ \\
\hline Sex & & & & & & \\
\hline Female & 108 & 76 & 23 & 70.3 & 21.3 & 55.0 \\
\hline Male & 228 & 123 & 16 & 54.4 & 7.0 & 7.0 \\
\hline Age & & & & & & \\
\hline Old & 325 & 134 & 37 & 41.0 & 11.0 & 25.9 \\
\hline Young & 11 & 2 & 2 & 18.2 & 18.2 & 100.0 \\
\hline Breeds & & & & & & \\
\hline $\begin{array}{l}\text { Cross } \\
\text { breeds }\end{array}$ & 226 & 95 & 26 & 42.0 & 11.5 & 27.4 \\
\hline Zebu & 110 & 44 & 12 & 40.0 & 10.9 & 27.3 \\
\hline
\end{tabular}

Table 3: Risk factors associated with Lumpy Skin disease in cattle in Namisindwa district 


\begin{tabular}{|c|c|c|c|c|}
\hline Risk factors of LSD & Odds Ratio & Std. Error & z-Statistic & $P>|z|$ \\
\hline Constant & .0175775 & .0100023 & -7.10 & 0.000 \\
\hline Introduction of new animals & 3.897781 & 3.187333 & 4.66 & 0.006 \\
\hline Contact at communal grazing point & 10.20908 & 8.33083 & 2.85 & 0.004 \\
\hline Rearing sheep \& goats & 5.264894 & 5.868739 & 1.49 & 0.136 \\
\hline Challenge with biting flies & 1.773285 & 1.959877 & 0.52 & 0.604 \\
\hline Animal trading occurrences & 2.130692 & 2.314266 & 0.70 & 0.486 \\
\hline Challenge with ectoparasites & 20.0593 & 17.87639 & 3.36 & 0.001 \\
\hline Access to veterinary services & .3611569 & .300341 & -7.22 & 0.044 \\
\hline Lack of vaccination & 1.577142 & 1.070752 & 0.67 & 0.502 \\
\hline Log likelihood & -42.78132 & & & \\
\hline Number of Obs. & 316 & & & \\
\hline LR chi2(8) & 346.91 & & & \\
\hline Prob> chi2 & 0.0000 & & & \\
\hline Pseudo R2 & 0.8022 & & & \\
\hline
\end{tabular}

\section{Figures}




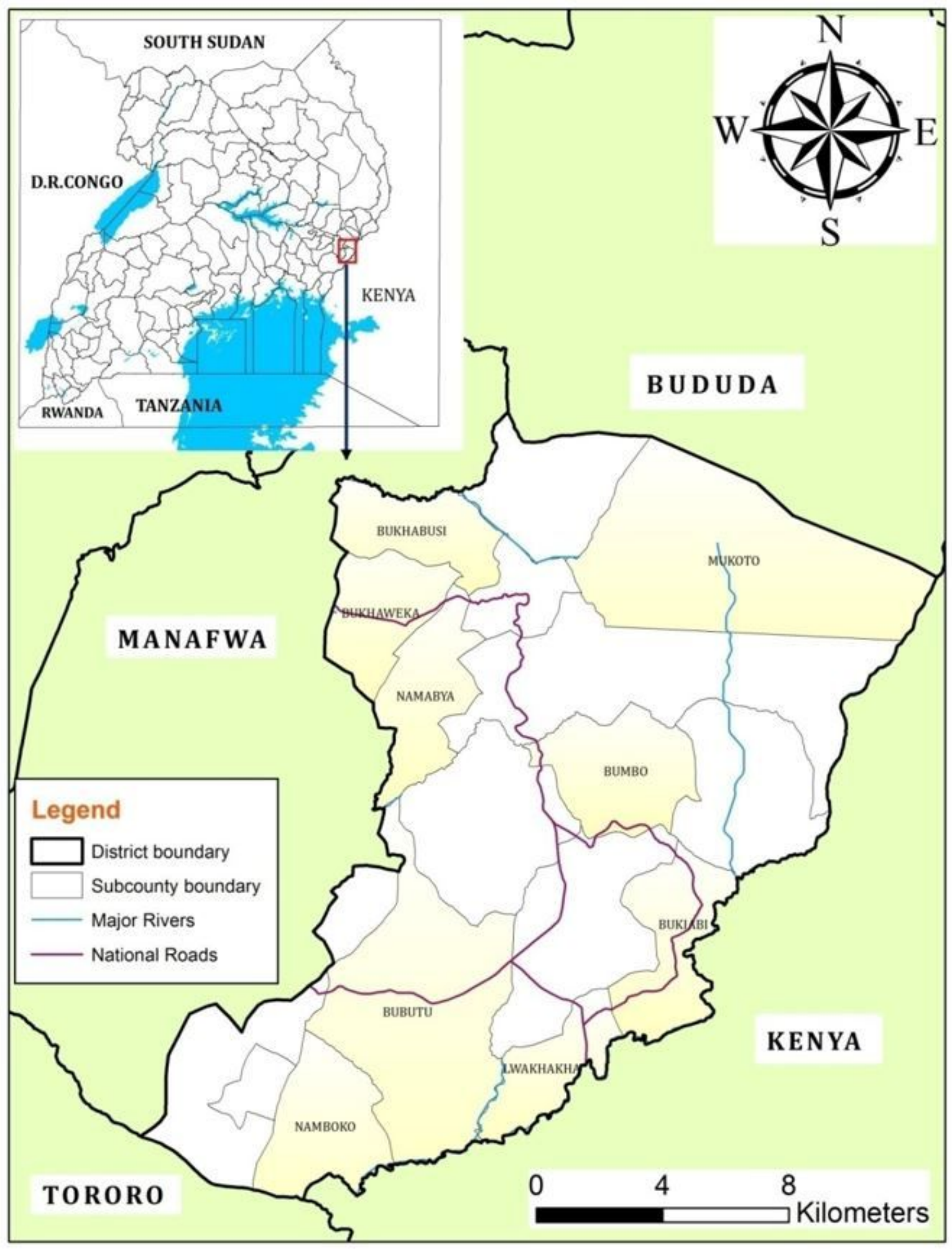

Figure 1

Map showing Namisindwa District with selected sub counties of study (Source: created during this study) Note: The designations employed and the presentation of the material on this map do not imply the expression of any opinion whatsoever on the part of Research Square concerning the legal status of any country, territory, city or area or of its authorities, or concerning the delimitation of its frontiers or boundaries. This map has been provided by the authors. 


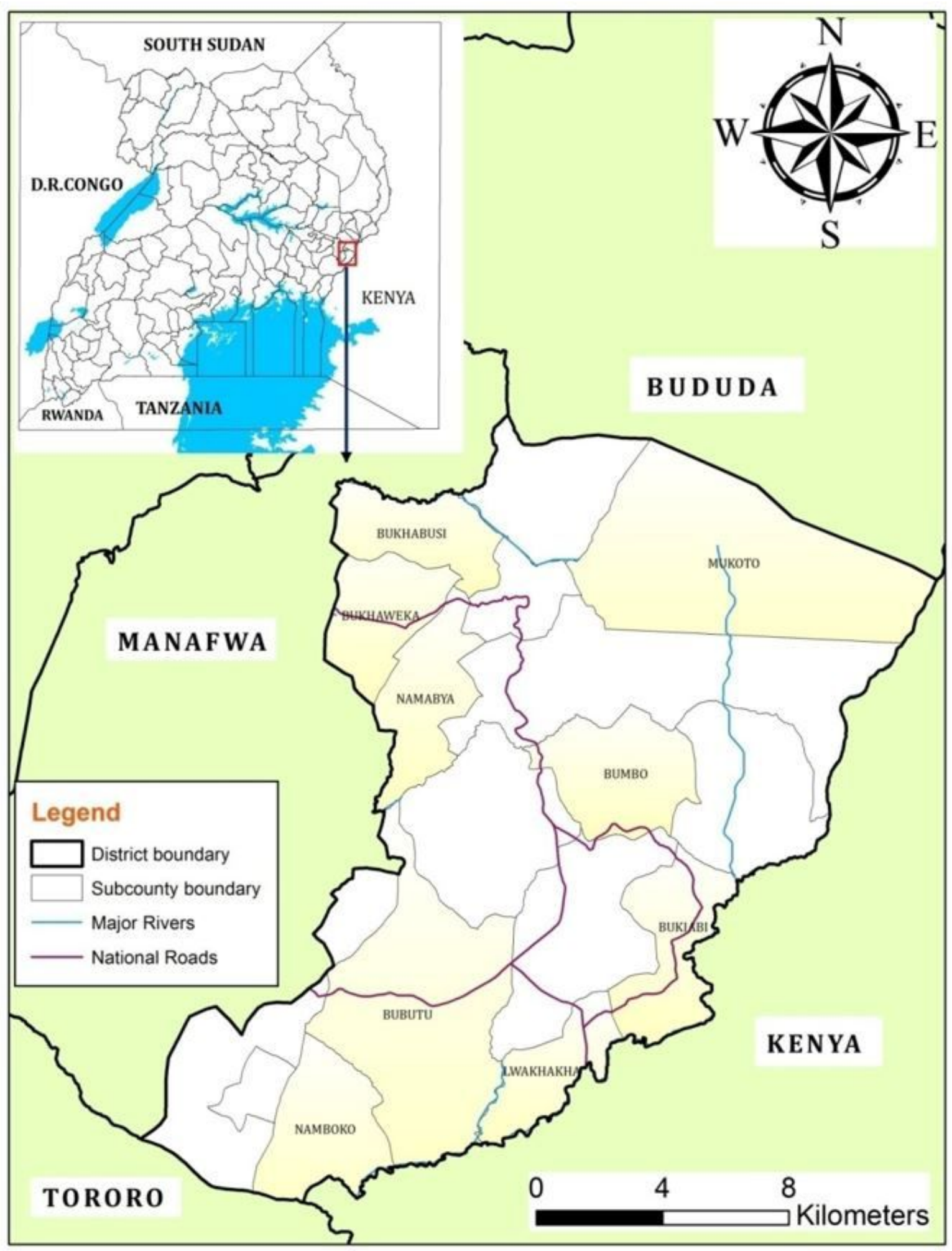

Figure 1

Map showing Namisindwa District with selected sub counties of study (Source: created during this study) Note: The designations employed and the presentation of the material on this map do not imply the expression of any opinion whatsoever on the part of Research Square concerning the legal status of any country, territory, city or area or of its authorities, or concerning the delimitation of its frontiers or boundaries. This map has been provided by the authors. 


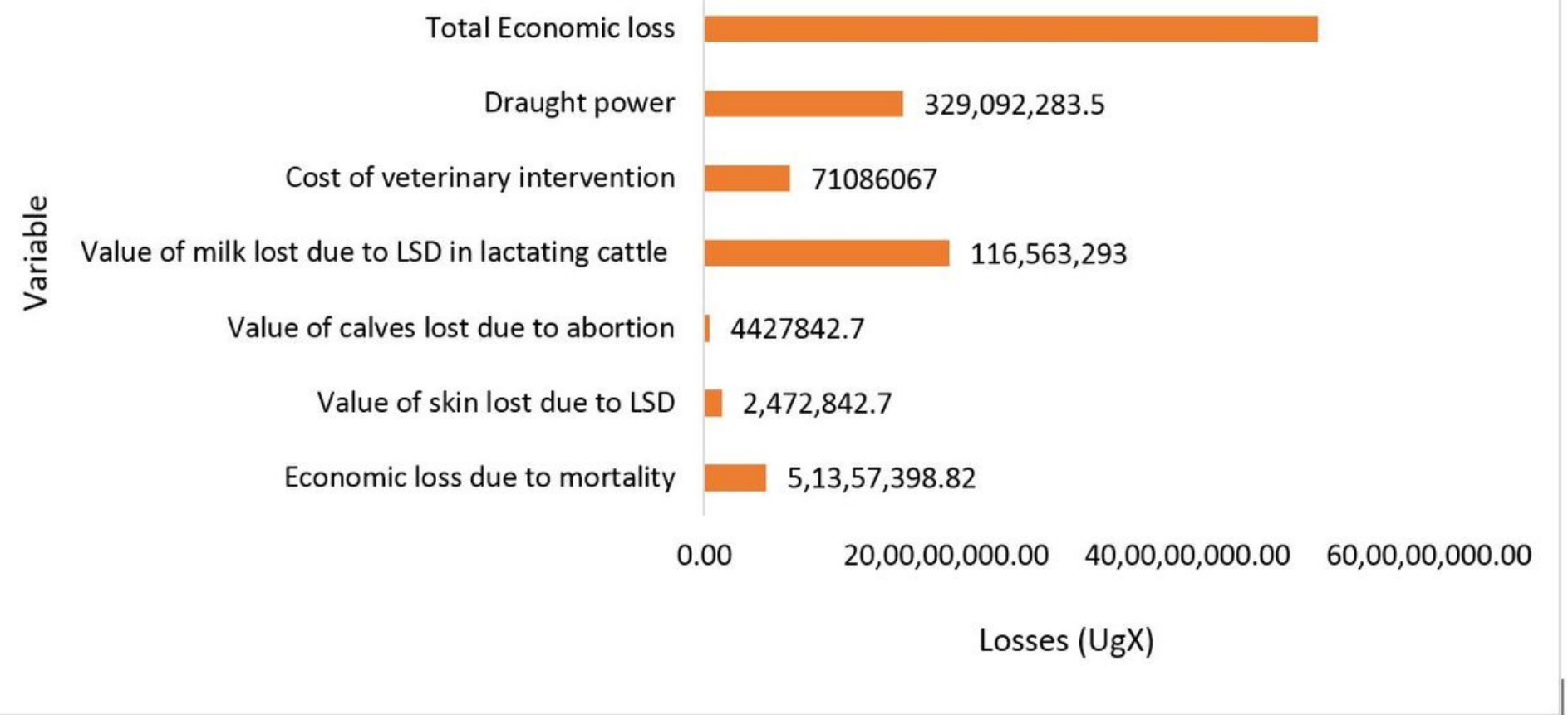

\section{Figure 2}

Contributors of economic loss due to LSD infections in cattle

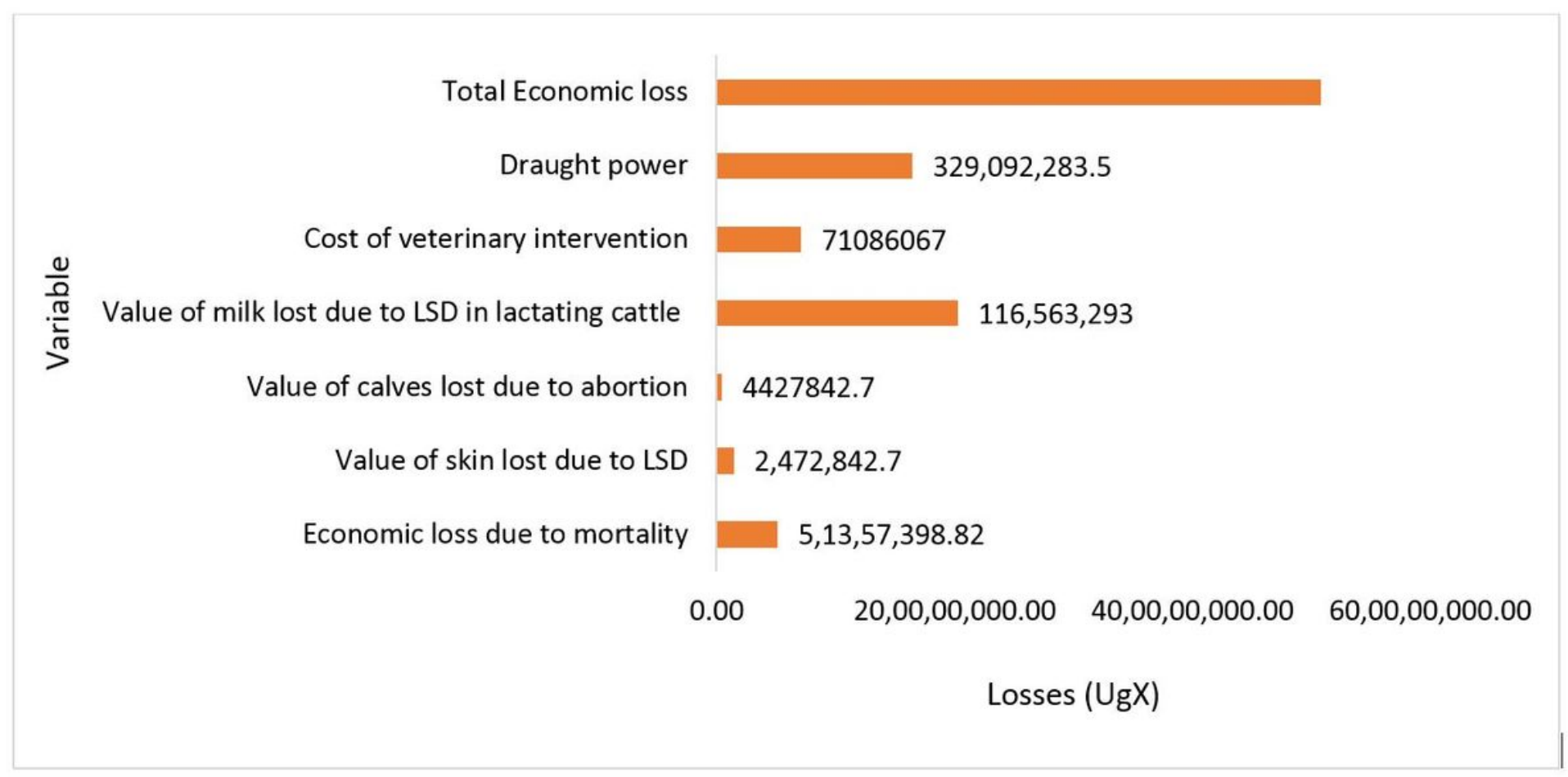

Figure 2

Contributors of economic loss due to LSD infections in cattle 


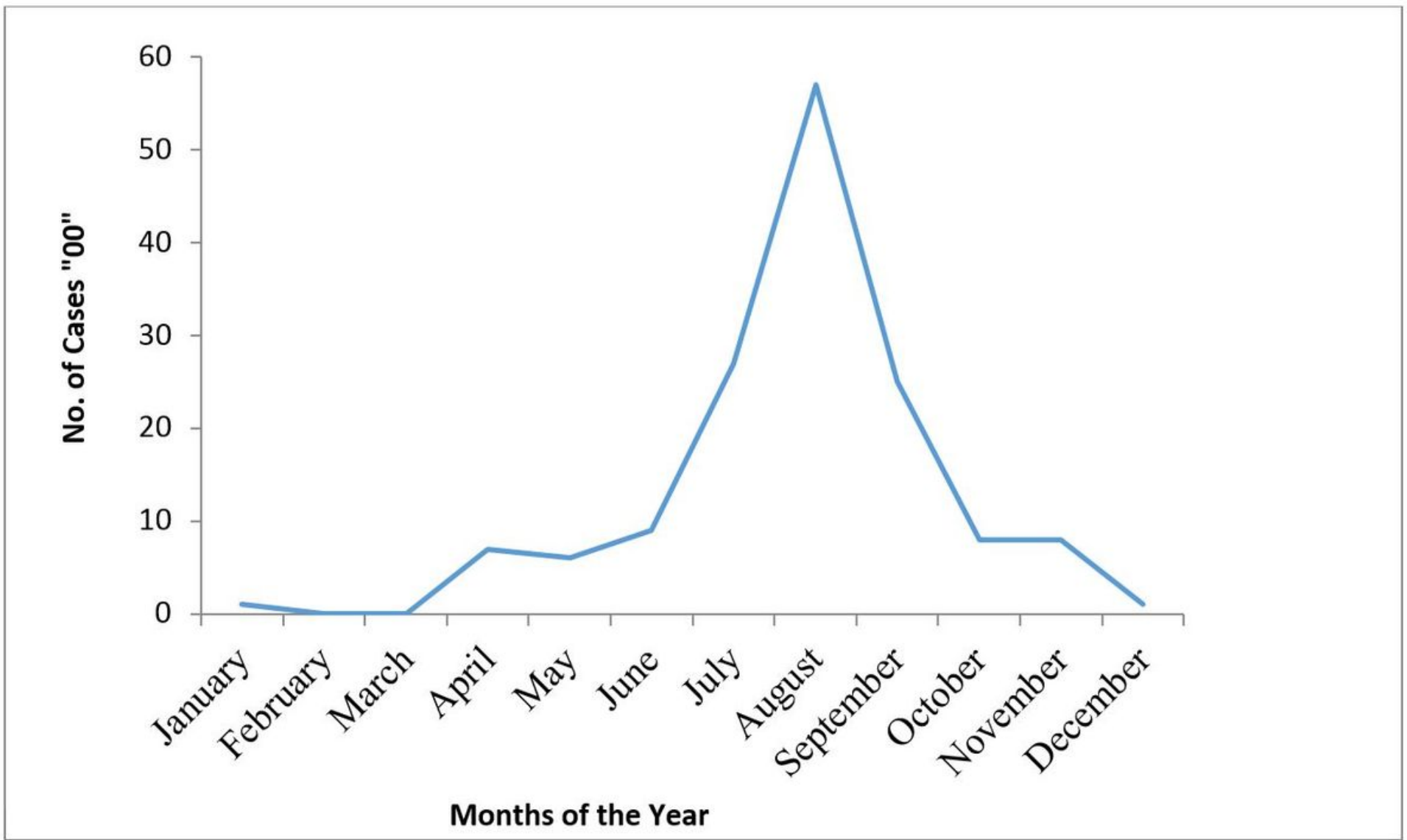

Figure 3

Annual distribution of LSD during the time of the outbreak. Going by this figure, the disease incidence coincides with months of rainfall. 


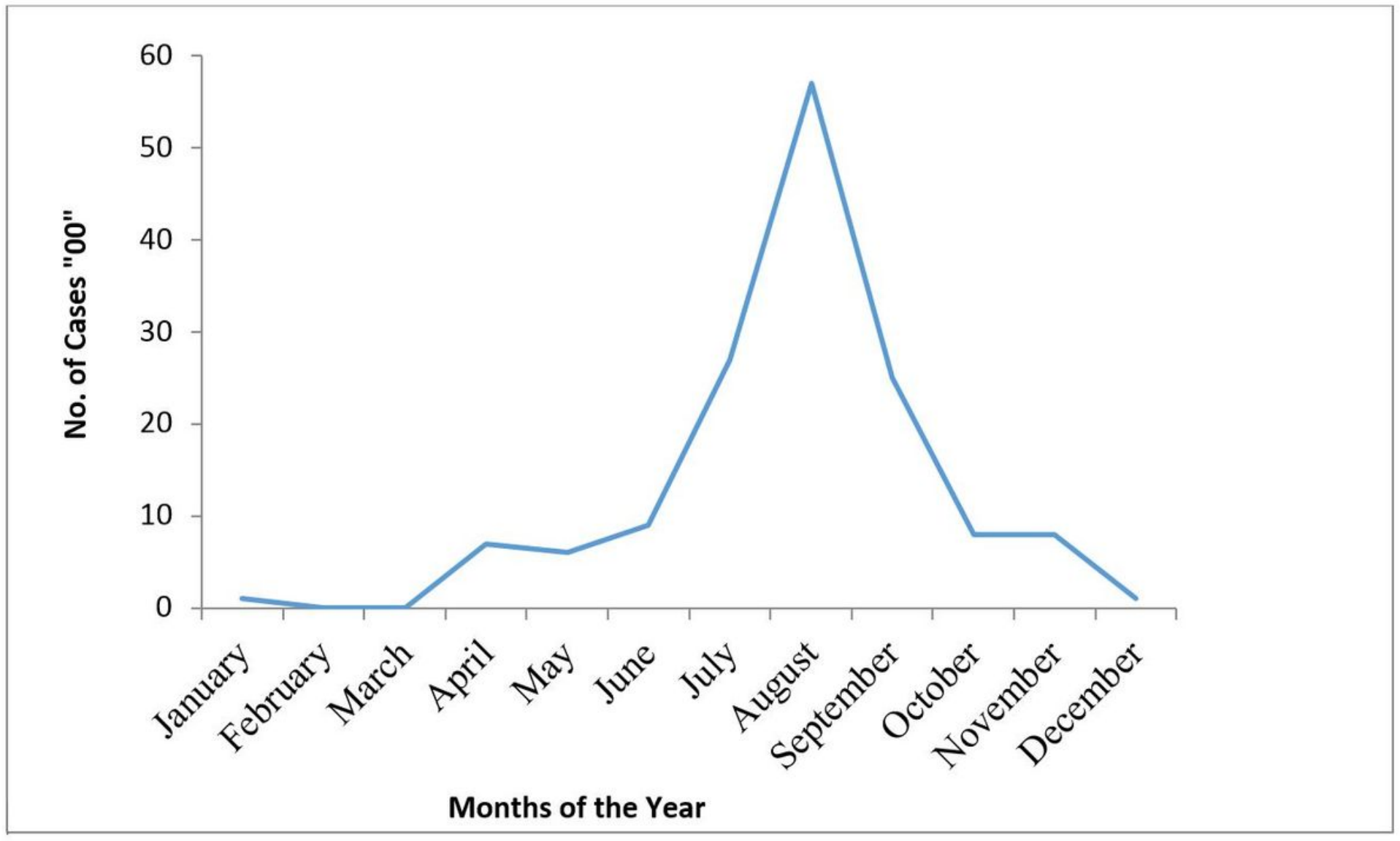

\section{Figure 3}

Annual distribution of LSD during the time of the outbreak. Going by this figure, the disease incidence coincides with months of rainfall. 